\title{
INOVASI DESAIN LURIK PEDAN PADAACESORIES INTERIOR SEBAGAI PENGEMBANGAN PRODUK UNGGULAN
}

\author{
Siti Badriyah \\ Jurusan Desain Interior Fakultas Seni Rupa dan Desain \\ Institut Seni Indonesia Surakarta \\ Jl. Ki Hajar Dewantara 19 Kentingan, Jebres, Surakarta 57126
}

\begin{abstract}
ABSTRAK
Lurik Pedan adalah produk kekayaan potensi daerah yang merupakan warisan budaya yang sangat berharga sebagai produk unggulan kota Klaten. Produktivitasnya hingga kini masih tersisa meskipun beberapa banyak yang sudah gulung tikar pengusaha pada industry ini. Di era global yang sangat kompetitif industri kain tradisional harus berbenah dengan berbagai alternative untuk mempertahankan eksistensinya. Melalui inovasi desain sebagai pengembangan produk akan memberikan solusi untuk meningkatkan daya saing dan mempertahankan kelestarian produk warisan tersebut. Lurik dengan beragam motif yang khas bisa dimanfaatkan melalui pengembangan inovasi desain pada segmen acesoris interior. Dengan memperhatikan karakter spesifik Lurik akan tetap ditampilkan secara khas melalui ide desain sehingga dapat memberikan stimulus bagi pengrajin untuk mengembangkan ketrampilan secara sederhana namun tetap mempertahankan kekhasannya.
\end{abstract}

Kata kunci: Lurik Pedan, inovasi desain , acesories interior, produk unggulan.

\begin{abstract}
Lurik Pedan is a local product that becomes a valuable cultural heritage as a seeded product of Klaten. The productivity still can be found eventhough some producers have closed their industries. In this very competitive global era, industry of traditional textilehas to move to the various alternates in order to keep their existences. Design innovation as the product development will provide solutions to increase competitiveness and keeping the preservation of heritage product.Lurik with various special motives can be used through the development of design innovation on interior accessories. The specific character of Lurik will surely and specifically presented through the design ideas so that it gives stimulus to the pengrajin to mengembangkan ketrampilan sederhana by preserving its characteristic.
\end{abstract}

Keywords: Lurik Pedan, design innovation, interior assesories, seeded product.

\section{A. Pengantar}

Kain lurik Pedan, Klaten merupakan produk industri kain lokal yang harus dilestarikan keberadaannya, baik itu teknis pembuatannya yang masih tradisional menggunakan ATBM maupun motif pola lurik yang memiliki ciri khas yang unik. Produksinya mampu menopang perekonomian masyarakat daerah sebagai sumber penghasilan bagi peningkatan kesejahteraan secara meluas. Namun tidaklah mudah bagi industri tradisional kain lurik ini menghadapi persaingan dengan industri tekstil modern , banyak permasalahan yang mesti diatasi yang sangat membutuhkan atensi berbagai pihak untuk tetap mengkonservasi produk unggulan daerah dengan ciri khas karakternya serta meningkatkan produktifitas agar semakin mantap dan berdaya bersaing di pasar global.
Peningkatan produktifitas disini akan melebar pada beberapa kriteria salah satunya adalah diversifikasi produk (pengembangan produk) dan proses yang lebih fleksibel, aman, ramah lingkungan , serta pemanfaatan tehnologi dalam manjemen dan pemasaran ), melalui diversifikasi produk (berbahan dasar kain lurik) yang menempatkan efisiensi pada input maupun output produk sebagai alternatif upaya peningkatan produktifitas pada industri kain lurik ini. Hal ini akan menyangkut pada peningkatan sumber daya manusia yang berarti meningkatkan pula industry padat karya, semakin berkembangnya model penyajian produk menjadi beragam produk berbahan dasar kain lurik akan meningkat pula pengelolaan produk baik yang bersifat internal produk maupun eksternal. Teknik maupun hasil tenun sudah sejak dahulu dikenal dan dikerjakan hampir di seluruh pelosok kepulauan Indonesia, sebagai salah satu 


\section{GEARR hamisanibuson}

warisan budaya bangsa yang patut dibanggakan. Terlebih bangsa Indonesia sejak berabad-abad telah menguasai berbagai teknik pertenunan, seperti tenun songket, tenun ikat pakan atau ikat lungsi, dan tenun ikat berganda. Temuan-temuan berupa alat-alat keperluan memintal, menenun dan sebagainya dapat dijadikan sebagai petunjuk akan kekayaan tersebut. Bahkan diperkuat dengan beberapa temuan berbentuk prasasti, arca dan relief pada beberapa candi Hindu, yang memberikan indikasi adanya teknik tenun yang sudah dikenal pada jamannya dan ada pula petunjuk berupa karya sastra. Dibutuhkan perhatian dari berbagai elemen bangsa untuk ikut melestarikan warisan budaya baik teknik maupun rupa produk budaya ini. Dengan beberapa atensi dari pihak-pihak yang terkait akan mampu menjaga eksistensinya. Salah satunya adanya pameran produk khusus tenun yang diselenggarakan Kementerian Perdagangan melalui Direktorat Jenderal Pengembangan Ekspor Nasional (Ditjen PEN) turut mendukung penyelenggaraan Pameran Adiwastra Nusantara yang berlangsung pada 19-23 Februari 2014, di Jakarta Convention Center, Jakarta, dan dibuka oleh Menteri Pariwisata dan Ekonomi Kreatif Mari Elka Pangestu. Pameran sebagai pembuka melapangkan kemungkinan-kemungkinan pengembangan lebih luas dan mendorong kekeuatan-kekuatan penggagas kelestarian Lurik dan tenun Indonesia. ${ }^{2}$

Dari sekian banyak jenis kain yang terdapat di Indonesia, salah satu yang sangat menarik bagi penulis adalah kain tenun Lurik. Dibalik kesederhanaan tampilan maupun dalam cara pembuatan, ternyata memiliki nilai luhur dan sarat makna. Berbagai kain tenun Lurik di Indonesia tidak hanya sebagai pakaian penutup saja. Namun lebih dari itu, kain tenun Lurik ini sering dikaitkan dengan berbagai makna simbolik kepercayaan serta ikut mengiringi berbagai upacara keagamaan, ritual, dan adat. Tenun Lurik dengan beragam coraknya dianggap memiliki nilai sakral dan dapat memberi tuah, ada pula yang mensiratkan nasehat, petunjuk, dan harapan. Pemanfaatan desain corak kain Lurik yang pakem akan banyak dapat termanfaatkan melalui inovasi desain accessories perlengkapan interior baik itu berupa art work, accessories interior seperti : interior ( armature untuk lighting, furnishing bedroom, dan furniture); Pemberdayaan kain lurik Pedan melalui diversifikasi produk berbahan dasar kain lurik yang menyasar secara khusus pada pemenuhan kebutuhan perlengkapan accessories interior resident maupun public space seperti hotel akan menjadikan arah desain secara tajam memproyeksikan pada kekuatan ide dan pengembangan bentuk yang layak bagi komsumsi interior mewah.

Kabupaten Klaten memiliki banyak pusat kerajinan seperti kerajinan gerabah di Melikan dan Bayat serta kerajinan bambubambu di daerah Delanggu merupakan aset yang bisa diberdayakan dengan mengintegrasikan Lurik masuk dalam sertiap desain produk gerabah dan berbahan dasar tanah liat serta bambu. Harapannya adalah adanya integrasi secara menyeluruh dalam bentuk produk dalam branding dan promosi Lurik sebagai kekhasan Klaten sebagai salah satu wilayah yang memiliki pusat tenun Lurik, Gerakan diversifikasi menjadi sangat potensial dalam pelaksanaan perencanaan inovasi produk Lurik ini jika ditunjang perhatian berbagai pihak untuk mendukung bersinerginya kolaborasi antar pengrajin dalam naungan industri yang lebih kuat menaungi keberlanjutannya. Perhatian banyak pihak akan sangat membantu dalam tumbuh kembang pesatnya industri produk yang karena kekhususannya mampu bersaing di pasar internasional. Terbukti banyak pesanan yang kadang kurang tertangani dari buyer luar negeri karena tuntutan desain yang kurang tercover baik dari segi desain maupun kuantitinya. Banyak faktor yang menyebabkan terkendalanya peningkatan produk dan kemajuan industri ini. Hingga pada akhirnya satu per satu akan gulung tikar tergilas oleh produk tekstil modern pabrikan yang bermodal besar. Branding sebuah wilayah sangat penting dalam pembentukan profil dan pemanfaatan sumber daya lokal dalam mengangkat nilai sebuah wilayah. Berkesinambungannya sebuah kerajinan satu dengan yang lain menjadi salah satu cara unntuk memasarkan potensi daerah dengan skala besar, tidak dengan hanya satu produk, tetapi dengan berbagai produk yang mempunyai ciri khas yang menonjol.

\section{B. Pembahasan}

Dinamakan Lurik karena berasal dari bahasa Jawa Kuno yakni 'lorek' yang berarti lajur atau garisgaris belang dapat pula berarti corak. Sesuai dengan namanya, kain tenun ini juga memiliki motif garis- garis yang melambangkan kesederhanaan. Menurut Widodo (2008), tenun Lurik merupakan tenun yang bermotif garis- garis. Lurik berasal dari istilah Jawa, yaitu 'rik' yang berarti garis. Istilah Lurik hanya digunakan di Jawa, namun dengan istilah yang berbeda, kain tenun yang menyerupai Lurik juga terdapat di Sumatera, Bali, Lombok, Sumba, Timor. 
Di luar Jawa, tenun Lurik sering digabung dengan teknik lain seperti ikat dan songket. Menurut Dhorofi (2007), "Lurik pada dasarnya berupa susunan garisgaris dari berbagai warna yang membentuk barisan ragam hias. Garis-garis yang lurus mengesankan ketegasan dan kedinamisan. Corak Lurik merupakan ucapan kekuatan dan semangat pantang menyerah warga Jawa tengah dalam menghadapi kehidupan mereka".

Pada jaman dahulu, kain Lurik ditenun dengan menggunakan benang katun yang dipintal dengan tangan dan ditenun menjadi selembar kain dengan alat yang disebut 'gedog', alat ini menghasilkan kain dengan lebar $60 \mathrm{~cm}$ saja. Alat tenun yang digunakan pun cukup sederhana yakni bernama bendho dan tenun gendong. Keduanya terbuat dari bambu atau batang kayu. Disebut alat tenun bendho karena alat yang digunakan untuk merapatkan benang berbentuk bendho (golok) sedangkan untuk gendong karena salah satu bagiannya diletakkan di belakang pinggang saat menenun. Dalam perkembangannya saat ini, proses pemintalan kain katun sudah dilakukan secara modern dengan menggunakan mesin. Salah satu ciri khas dari kain Lurik adalah penggunaan benang katun yang akan menghasilkan tekstur yang khas pada kain Lurik ini. Sehingga sebuah kain bermotif Lurik yang dipintal dari benang polyester, tidak dapat disebut sebagai kain Lurik, karena teksturnya akan sangat berbeda dengan kain Lurik yang terbuat dari katun. Seiring dengan perkembangan jaman pula, kain Lurik mulai diproduksi dengan menggunakan ATBM /Alat Tenun Bukan Mesin yang lebih modern dan dapat menghasilkan kain dengan lebar $150 \mathrm{~cm}$.

Kain tenun lurik dengan teksturnya yang khas, memiliki kelenturan serta kekuatan yang baik, sehingga penggunaannya tidak terbatas hanya pada pemakaian sehari-hari saja seperti baju 'klambi' atau kain gendong saja, namun dapat juga digunakan sebagai perlengkap interior ruangan. Keunikan dari kain lurik adalah ketika masih baru teksturnya memiliki permukaan sangat kasar dan kaku, namun ketika telah digunakan beberapa lama, teksturnya dapat berubah menjadi lebih lembut namun tidak berkurang kekuatannya.

Motif kain tenun lurik pun masih sangat sederhana pada awal kehadirannya. Dibuat dalam warna terbatas hanya hitam dan putih atau kombinasi keduanya, kemudian mulai berkembang dengan menggunakan beragam corak warna. Proses pembuatan Lurik juga sangat sederhana. Dimulai dengan menyiapkan benang yang berasal dari tumbuhan perdu dan warna dominan hitam dan putih. Benangpun diberi rendaman daun pohon tom yang menghasilkan warna nila, biru tua dan hitam serta coklat dari batang mahoni. Perbedaan antara satu corak dengan corak lainnya adalah susunan/komposisi warna dan jumlah garis, misalnya Lurik telupat /tigaempat, coraknya terdiri dari 3 garis dan 4 garis berwarna biru tua yang berselang -seling, dengan kain berwarna dasar hitam. Angka 3 dan 4 apabila dijumlahkan akan menjadi 7 sebagai angka keramat dalam kepercayaan tradisional Jawa. Selain itu bagi masyarakat Jawa angka 7 juga melambangkan kemakmuran. Masing-masing komposisi warna dan garis pada kain lurik memiliki makna tertentu. Seperti kain Lurik gedog madu, digunakan pada upacara mitoni atau siraman; kemudian ada lagi kain lurik motif lasem umumnya digunakan untuk perlengkapan pengantin. Bahan pewarnapun kini banyak ditemukan di pasaran(naptol dan Lindhetren) hanya pengusaha tertentu yang lebih memilih pewarna alam, karena disamping bahan pewarna yang tidak mencukupi atau terbatas (waktu dan penjual) akan tetapi bahan inipun kadang tidak bisa ada sewaktu waktu. Meskipun sebenarnya sumber daya alam kita mencukupi untuk dikelola secara professional dalam pengadaannya. Efek visualnya pun tidah se-bright warna kiamiawi, hanya dikerjakan sesuai order buyer yang menginginkan bahan yang ramah lingkungan saja.

Kain tenun lurik umumnya digunakan untuk pakaian sehari- hari. Namun corak/motif Lurik pun dibedakan untuk kalangan keraton dan masyarakat umum. Untuk wanita biasanya dibuat kebaya atau kain bawahan. Sedangkan untuk pria dipakai untuk beskap atau surjan. Selain itu lurik juga seringkali digunakan untuk berbagai upacara kepercayaan seperti labuhan, ruwatan, siraman, mitoni dan lainlain. Meskipun motif dasar lurik hanya berupa garis, namun ILurik memiliki banyak variasi dan ragam corak atau motif seperti corak klenting kuning, sodo sakler, lasem, tuluh watu, lompong keli, kinanti, kembang telo, kembang mindi, melati secontong, ketan ireng, ketan salak dan lain-lain. Perpaduannya pun tidak hanya garis melainkan juga kotak-kotak, dua garis vertikal serta horizontal.

Filosofi dan makna sehelai lurik biasanya ercermin dalam corak/motif dan warna kain tenun lurik tersebut. Ada corak- corak yang dianggap sakral yang memberi nilai tuah, ada yang memiliki nilai nasehat, petunjuk dan juga harapan. Seperti daur kehidupan manusia mulai dari lahir hingga saat meninggal, dapat diibaratkan dengan putaran empat penjuru mata angin yang bergerak dari timur ke selatan dengan melalui 


\section{GEELRR Jumal sori Busuya}

barat menuju ke utara. Keempat penjuru mata angin ini dalam bahasa Jawa disebut dengan istilah 'mancapat'. lurik juga tidak terlepas dari berbagai mitos yang tumbuh dan berkembang secara turun temurun dalam kelompok masyarakat. Berbagai unsur seperti warna, motif, dan kepercayaan yang menyertainya membuat nilai sebuah lurik kian menjadi tinggi. Penggunaan kain tenun lurik terutama di daerah Solo dan Yogya, umumnya dipakai dalam penyelenggaraan upacara tertentu, dan juga memiliki makna yang berbeda-beda, tergantung dari maksud dan tujuan upacara yang diselenggarakan.

Kain tenun lurik ini merupakan sebuah warisan kekayaan intelektualitas serta kreativitas leluhur. Kesederhanaan yang terpancar dari motif kain tenun lurik dengan berbagai maknanya yang mendalam, merupakan perwujudan dari nilai-nilai kebudayaan yang ditanamkan dari para leluhur kepada generasi berikutnya. Bahkan, keberadaan kain tenun lurik hingga saat ini merupakan cerminan apresiasi generasi penerus terhadap karya seni budaya bangsa. Tampilan permukaan pada tekstur sehelai kain tenun lurik, dapat ditentukan oleh: (1) Jenis bahan baku, apakah serat kapas, serat kayu, serat sutera, ataupun serat sintetis. (2) Jenis pintalan, apakah benang pintal tangan atau pintal mesin. (3) Jenis benang, besar kecilnya benang akan mempengaruhi kehalusan tenunan. (4) Jenis alat tenun, apakah menggunakan alat tenun gendong, ATBM atau ATM.

Kain Panjang. Kain panjang berukuran satu meter kali dua setengah meter. Biasanya kani panjang ini mempunyai tumpal yang terdiri dari batuk dan seret untuk kanan kiri, telisir untuk pinggir kain bagian atas dan bawah dan badan kain terletak di tengah.

Kain Tenun Lurik produksi Solo, Yogyakarta dan sekitarnya berbentuk: (1) Jarit atau (2) Kain Sarung. Kain sarung mempunyai tumpal lebar 60 centimeter, telisir untuk pinggir kain bagian atas, bawah dan badan sarung. Umumnya berukuran 1 meter kali 2 meter. (3) Kain Ciut (sempit). Kain Ciut atau kain kemben berukuran setengah meter kali dua meter atau tiga meter. umumnya berukuran setengah meter kali tiga meter. Telisir lebih kecil menggunakan benang ganda agar lebih kuat, dan biasa digunakan untuk selendang gendong. (4) Stagen atau ikat pinggang. Stagen berukuran $15 \mathrm{~cm} \times 350 \mathrm{~cm}$, biasanya digunakan saat mengenakan kain panjang. (5) Bakal Klambi (bahan pakaian). Biasanya berukuran satu meter kali dua setengah meter, tanpa tumpal. Bakal klambi ini digunakan untuk busana daerah, seperti Surjan dan Sruwal (celana prajurit Kraton Yogyakarta).
Sebagaimana telah diungkapkan bahwa sudah sejak dahulu tenun lurik merupakan kerajinan pakaian rakyat, sedangkan batik yang lebih muda usianya dianggap lebih tinggi tingkatannya dan bersumber dari kalangan keraton. Anggapan tersebut diatas tidak seluruhnya benar. Pada dasarnya kain lurik juga dipakai oleh kaum ningrat dan masih dipakai hingga sekarang. Terutama pada peristiwa tertentu terlihat pemakaian kain lurik dengan corak dengan makna tertentu terkait dengan peristiwa adat maupun upacara tradisional di Yogyakarta.

Produk kerajinan kain tenun ATBM menggunakan alat manual yang sebagian besar menggunakan tenaga manusia sebagai penggeraknya. Produk tenun menjadi unik dan menarik ketika melihat proses rangkaian benang menjadi satu kesatuan tenunan kain, selendang ataupun lap makan yang indah. Benang yang dipakai pun berbeda sesuai dengan jenis produknya. Mulai dari benang yang kasar hingga halus, dapat terlihat dari hasil tenunannya.

Istilah yang perlu diketahui dalam pertenunan yaitu 'benang lusi' dan 'benang pakan'. Benang lusi adalah benang kain tenun yang terletak memanjang kearah panjang kain. Dalam proses pembuatan kain, benang lusi ini banyak mengalami ketegangan dan gesekan. Oleh karena itu benang lusi harus dibuat sedemikian rupa dan kuat sehingga mampu menahan tegangan dan gesekan. Umumnya untuk memperkuat benang lusi dengan menggunakan benang rangkap dan di-gintir. Jika berupa benang tunggal, maka sebelum dipakai harus diperkuat terlebih dahulu melalui proses penganjian (diberi kanji). Benang pakan adalah benang melintang ke arah lebar kain tenun. Benang ini mempunyai kekuatan yang relatif lebih rendah daripada benang lusi.

Masing- masing komposisi warna dan garis pada tenun lurik memiliki nama tertentu. Seperti komposisi garis dan warna Lurik 'telupat' akan berbeda dengan corak 'sulur ringin', berbeda pula dengan corak 'sodo sak ler' dan sebagainya. Kain lurik polos yang hanya memiliki corak garis melintang di bagian kedua ujungnya disebut kain 'pankung'. Kain bercorak garisgaris dan berwarna hitam dan putih atau hijau dan putih disebut 'pulowatu'. Sedangkan kain lurik yang disebut kain 'pribul' memiliki kombinasi dua atau tiga buah garis dan kain namanya terdiri dari beberapa garis yang memiliki beberapa gradasi dari satu warna yang sama. 


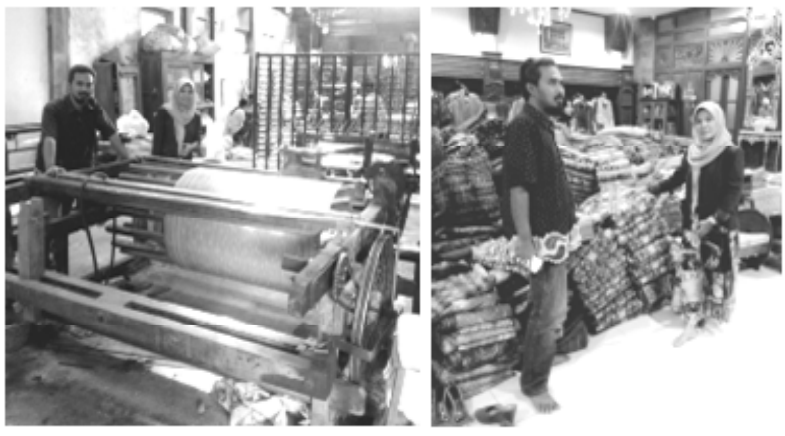

Gambar 1. Salah satu sudut workshop industri kain lurik Tradisional di Pedan, dan showroomnya (Foto: Siti Badriyah, 2016)

Ada satu jenis kain Lurik yang lebarnya hanya 15 sentimeter yang memiliki tenunan sangat rapat dan dibuat pada alat tenun kecil. Kain itu disebut kain 'bendho' dan umumnya berwarna hitam, hijau tua atau merah tua sebagai 'stagen'. Kain tenun lurik memiliki banyak filosofi, semua pengerjaannya masih konvensional mulai dari pemintalan benang hingga penenunan dilakukan secara manual dan tradisional. Bahan baku yang berasal dari benang ini kemudian dipintal oleh sejumlah pekerja yang sudah tidak lagi muda. Setelah proses pemintalan 'ngelos' dilakukan, kemudian dilanjutkan penggabungan sejumlah benang yang berbeda warna untuk menjadi dasar dari proses penenunan, untuk kemudian dilakukan proses penenunan. Meskipun terlihat sederhana motifnya, namun ketrampilan dan kejelian dalam memadukan warna(dalam interior sangat penting dalam meninjau dalam psikologi warna ${ }^{3}$, karna aplikasinya sebagai tekstil interior yang merupakan bagian dari integritas taste of space serta tata susunan kotak dan garisnya tampak serasi dan seimbang. Sehingga akan menghasilkan kain lurik yang indah dan mengagumkan.

Modifikasi kain lurik menjadi beragam produk, seperti pakaian maupun aksesori semakin digemari masyarakat. Kekhasan corak kain lurik tradisional dan proses pembuatannya yang masih konvensional dengan tangan, menyebabkan nilai jual produk kain lurik menjadi tinggi. Tak hanya pasar dalam negeri, kain lurik pun mulai merambah pangsa luar negeri. Sebelum ada upaya modifikasi, kain lurik sering kali dianggap kuno, tidak trendi, dan kusam. Kini, beragam gerai kerajinan seperti Lawe mulai memberikan sentuhan inovasi baru lewat pewarnaan yang lebih cerah dengan beragam motif. Namun, pembuatan kain lurik masih tetap dipertahankan secara tradisional dengan penggunaan alat tenun bukan mesin.
Pada masyarakat tradisional khususnya kain tenun selain memiliki fungsi praktis, yang juga memiliki fungsi lain, yakni sebagai sebuah simbol status. Beberapa motif maupun corak lurik tertentu memiliki kandungan nilai makna harapan. Pakaian yang dikenakan seorang bangsawan dengan status sosial tinggi tentu akan berbeda dengan rakyat biasa dengan status sosial rendah, baik dalam bentuk model maupun coraknya. Begitu pula pakaian yang dipakai dalam upacara tertentu akan sangat berbeda dengan yang pakainan keseharian.

Menurut Sugeng (2013), kata simbol berasal dari bahasa Yunani yaitu 'symbolom'yang berarti tanda atau ciri yang memberitahukan sesuatu kepada seseorang. Simbol merupakan bagian terkecil dari ritual yang menyimpan suatu makna dari tingkah laku atau kegiatan pada upacara ritual yang bersifat khas.

Pemahaman terhadap simbol dapat diidentifikasi sebagai kata benda, kata kerja dan kata sifat. Simbol sebagai kata benda dapat berupa barang, objek, tindakan dan hal-hal konkret lain. Simbol sebagai kata kerja dapat berfungsi untuk menggambarkan, menyelubungi, mengartikan, menunjukkan, memanipulasi, dan menandai. Simbol sebagai kata sifat berarti sesuatu yang lebih besar, lebih bermakna, lebih bernilai, dalam sebuah kepercayaan. Fungsi simbol digunakan untuk menjebatani objek atau hal -hal yang nyata dengan hal- hal yang abstrak yang maknanya melebihi dari makna hal yang tampak. Sesuai dengan keragaman karakter maupun status seseorang, maka pakaian yang digunakan juga beragam serta bervariasi. Pada masyarakat yang masih menjunjung tinggi nilai-nilai tradisi seperti pada beberapa kelompok suku bangsa di Indonesia, pakaian yang digunakan menunjukkan identitasnya. Sehingga pakaian bukanlah benda semata-mata atau materi yang dipakai tanpa memiliki makna apapun. Kain lurik misalnya, merupakan sebuah simbol, karena ia memiliki kandungan makna. Simbol merupakan tanda yang dapat ditafsirkan. Makna tersebut merupakan sesuatu yang tidak kasatmata, tetapi maknanya dapat ditafsirkan dibalik corak kain tenun lurik tersebut.

Simbol merupakan segala sesuatu benda, peristiwa, tindakan, ucapan, dan sebagainya yang telah dilekatkan makna tertentu. Sehingga simbol bukanlah milik individu, namun menjadi milik suatu entitas masyarakat tertetntu. Kain tenun lurik merupakan salah satu benda budaya karena dimiliki oleh suatu masyarakat tertentu. Benda ini merupakan wujud fisik dari ide, nilai, maupun norma yang mengatur dan memberi arah bagi masyarakat pada suatu 


\section{GE[AR Jurnal Seni Budaya}

kebudayaan tertentu, seperti juga yang diutarakan Smarts bahwa symbol-simbol dalam ornament peninggalan leluhur menjadikan suatu pesan dan diklasifikasi sebagai old sign ${ }^{4}$. Menurut Wahyono (1981), lurik juga dipergunakan sebagai benda upacara penting, bukan hanya kain tenun lurik, melainkan juga alat-alat tenun seperti kisi, suri, lawon, bahkan klinden (tali pada jantra) dan tali gun dianggap sebagai tolak penyakit. Fungsi kain tenun lurik antara lain: (1) Corak liwatan , sulur ijo, gedog untuk sesaji ruwatan, atau mitoni. (2) Corak palen dipakai untuk seserahan. (3) Corak dringin dipakai dalam upacara labuhan. (4) Lurik mresik dipakai untuk wanita yang sudah dewasa tetapi belum kawin. (5) Lurik dengkik dengan kemben lurik mrutu sewu dipakai lanjar (janda muda) di daerah wonogiri. (6) Lurik kantil dipakai wanita yang sudah memiliki keturunan sampai generasi ke-5 (wareng) di daerah Bagelan. (7) Lurik gembung limasan di pakai para lanjar.

\section{Beberapa Makna Simbolik Corak Lurik}

Meskipun corak /motif kain tenun lurik hanya terdiri dari garis-garis dan kotak-kotak, namun terkandung banyak makna simbolik. Hal ini karena lurik mempunyai makna tradisi, adat kepercayaan bagi orang Jawa baik di kalangan ningrat maupun kalangan rakyat biasa. Pada kain Lurik pemakaian berbagai corak ada kaitan dengan sifat upacara, kedudukan sosial serta keadaan seseorang, apakah seorang wanita, pria, muda, tua, perawan, perjaka atau sudah menikah. Ada beberapa corak mengandung perlambang sekumpulan harapan, diantaranya:

\section{Corak Kluwung}

Kluwung adalah pelangi, pelangi merupakan keajaiban alam dan tanda kebesaran Tuhan Sang Pencipta. Oleh sebab itu Lurik corak kluwung dianggap sakral serta mempunyai tuah sebagai tolak bala. Secara simbolis corak kluwung dilukiskan dengan garis -garis lebar beraneka warna bagaikan warna pelangi. Corak ini dipergunakan untuk berbagai upacara sakral dalam daur kehidupan manusia antara lain: (1) Upacara Mitoni, agar anak yang dikandung lahir selamat terhindar dari bala. (2) Upacara Labuhan, biasanya dilakukan oleh kerabat keraton untuk keselamatan. (3) Upacara Mantenan, biasanya diletakkan dibawah bantal penganten dengan harapan kedua mempelai mencapai keselamatan dan kebahagiaan dalam berumah tangga seperti pesona warna pelangi.

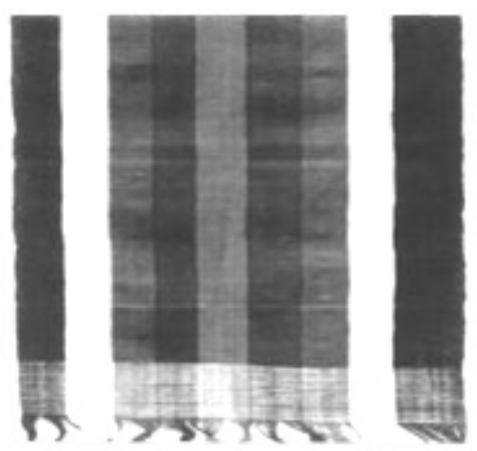

Gambar 2. Corak Lurik Kluwung (Sumber: Nian S. Djoemena, 2000)

\section{Corak Tuluh Watu}

Tuluh Watu berarti 'batu yang bersinar' dan dianggap bertuah sebagai penolak bala. Corak ini biasanya dipergunakan pada upacara Ruwatan Sukerta dan sebagai pelengkap sesajen upacara Labuhan. Tuluh dapat berarti pula kuat atau perkasa. Corak Tuluh Watu termasuk corak sakral yang dahulu hanya boleh dipakai oleh orang tertentu yang berkepribadian kuat dan berbudi luhur. Di pedesaan kaum wanita pedagang memakai corak ini dalam bentuk selendang untuk membawa barang dalam tugas sehari-hari karena mempunyai kekuatan juga sifat tenunannya kuat.

Dhorofi (2007) menambahkan fungsi tenun Lurik tradisional Yogyakarta dengan motif teluh watu atau 'batu bersinar' dianggap bertuah dan berfungsi sebagai tolak bala. Sampai sekarang teluh watuh digunakan untuk upacara labuhan yang diadakan setiap tahun baru Jawa di pantai laut selatan.

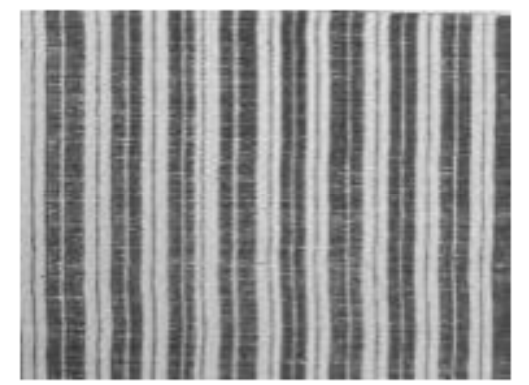

Gambar 3 . Corak Lurik Tuluh Watu, (Foto : Nian S. Djoemen,2000)

\section{Corak Tumbar Pecah}

Corak Tumbar Pecah diibaratkan orang memecah ketumbar dan seharum aroma ketumbar. Corak ini digunakan untuk upacara tingkeban atau mitoni dengan maksud agar kelahiran berjalan dengan lancar semudah memecah ketumbar, 
ibu dan anak dalam keadaan selamat dan kelak anak menjadi anak yang berguna dan harum namanya.

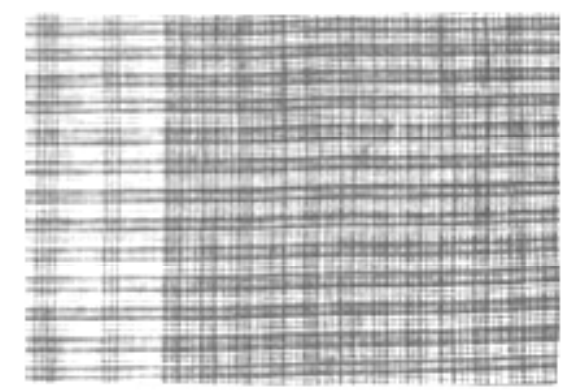

Gambar 4. Corak Lurik Tumbar Pecah, (Foto : Nian S. Djoemena, 2000)

\section{Corak Lompatan atau Liwatan (Solo)}

Lompatan artinya terlewatkan dari bahaya maut. Corak Lompatan biasanya digunakan sebagai kemben kelengkapan upacara mitoni. Untuk upacara mitoni biasanya dililitkan stagen bangun tolak sebagai pengikat kain panjang dan kemben pada perut ibu yang hamil sebagai penolak bala.

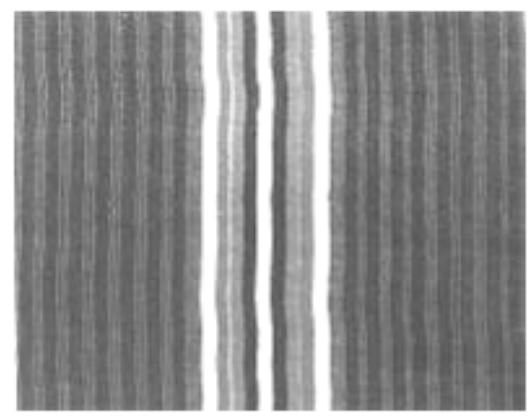

Gambar 5. Corak Lurik Lompatan/Liwatan, (Foto: Nian S. Djoemena, 2000)

\section{Corak Telupat}

Corak telupat berasal dari bahasa Jawa, telu artinya tiga dan papat artinya empat adalah corak lajuran yang berjumlah $7 /$ tujuh terdiri dari satu kesatuan kelompok dengan empat lajur dan satu lagi dengan jumlah tiga lajur. Angka 7 merupakan angka keramat yang dalam kepercayaan tradisional Jawa melambangkan kehidupan dan kemakmuran yang artinya merupakan pitulungan atau pertolongan dari yang Maha Kuasa. Corak ini diciptakan oleh Sri Sul$\tan \mathrm{HB}$ I.

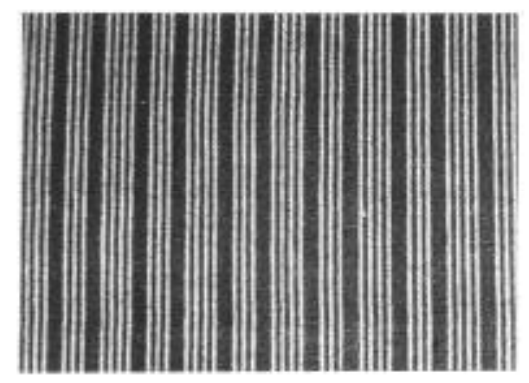

Gambar 6. Kain Lurik motif Corak Telupat (Foto: Nian S. Djoemena, 2000)

\section{Corak Sapit Urang}

Corak sapit urang yang berati jepit udang, adalah ungkapan simbolik suatu siasat perang, yaitu musuh dikelilingi atau dikepung dari samping dengan kekuatan komando menyerang berada di tengahtengah. Corak ini umumnya dipakai sebagai busana prajurit keraton.

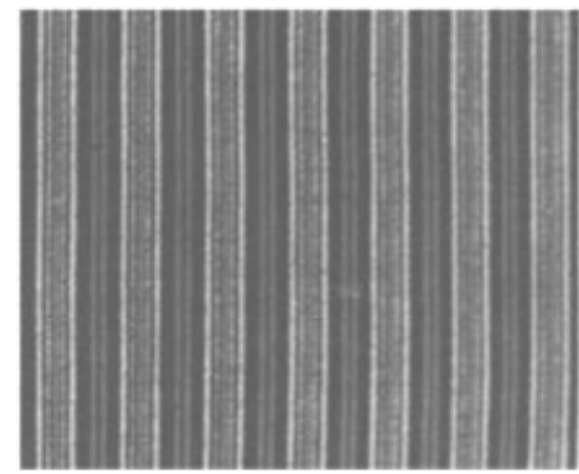

Gambar 7. Lurik Motif Corak Sapit Urang (Foto: Nian S. Djoemena,2000)

\section{Corak Udan Liris}

Corak udan liris ${ }^{5}$ artinya hujan gerimis, karena hujan mengandung konotasi mendatangkan kesuburan, maka corak ini merupakan lambang kesuburan dan kesejahteraan. Oleh karena itu pula corak udan liris merupakan salah satu corak yang dipakai oleh penguasa, dengan harapan si pemakai diberkahi oleh yang Maha Kuasa dan membawa kesejahteraan bagi para pengikutnya. Selain corak tersebut masih ada beberapa corak yaitu, corak mantri anom, corak prajurit ketanggung, corak prajurit mantri jeron. Semua corak ini yang biasa dipakai untuk pakaian surjan para prajurit keraton Yogyakarta dalam tugas sehari-hari di keraton. 


\section{GEELRR Jumal sori bustya}

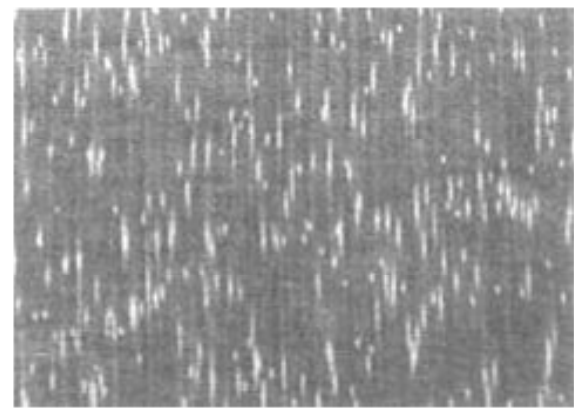

Gambar 8.Lurik Motif Corak Udan Liris, (Foto: Nian S. Djoemena,2000)

\section{Corak Dringin}

Corak Lurik dringin, kain ini mengandung makna agar anak yang dilahirkan kelak mempunyai jiwa rendah hati, sederhana, dan bisa membaur di dalam masyarakat.
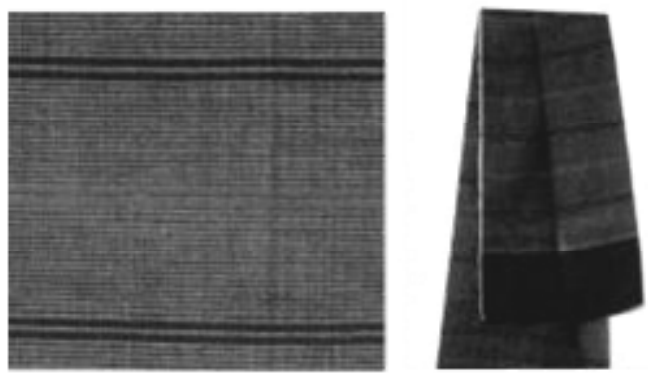

Gambar 9 . Lurik dengan Corak motif Dringin, (Foto: Nian S. Djoemena, 2000)

Branding sebuah wilayah sangat penting dalam pembentukan profil dan pemanfaatan sumber daya lokal dalam mengangkat value sebuah wilayah. Berkesinambungannya sebuah kerajinan satu dengan yang lain menjadi salah satu cara unntuk memasarkan potensi daerah dengan skala besar, tidak dengan hanya 1 produk, tetapi dengan berbagai produk yang mempunyai ciri khas yang menonjol.
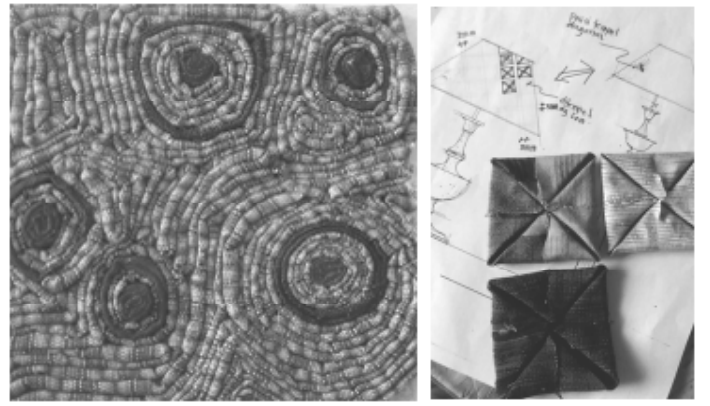

Gambar 10. Elemen acesories dari bahan limbah kain Lurik Pedan

(Foto: Siti Badriyah, 2017)
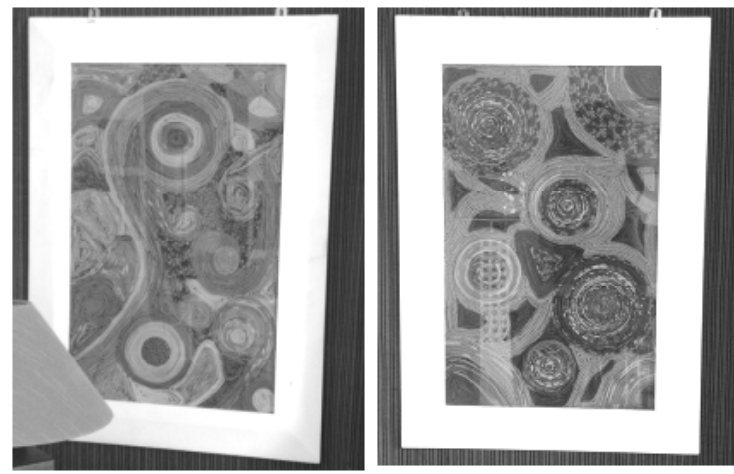

Gambar 11. Beberapa Produk Art work dari limbah lurik Pedan hasil PPM Hilink 2016

(Foto : Siti Badriyah, 2016)

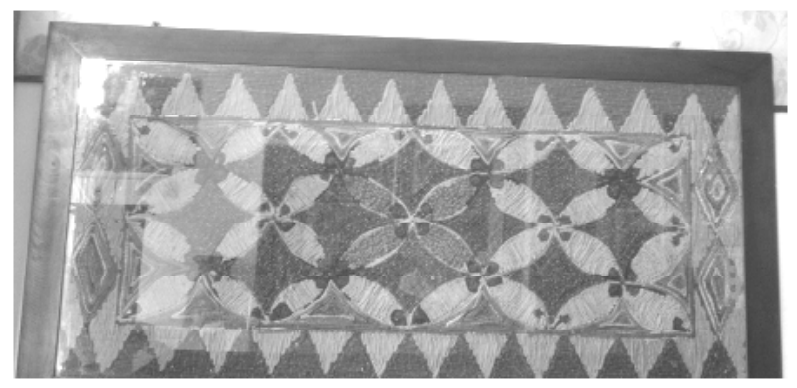

Gambar 12. Art work motif Kawung berbahan limbah kain Lurik pedan

(Foto: Siti Badriyah, 2017)

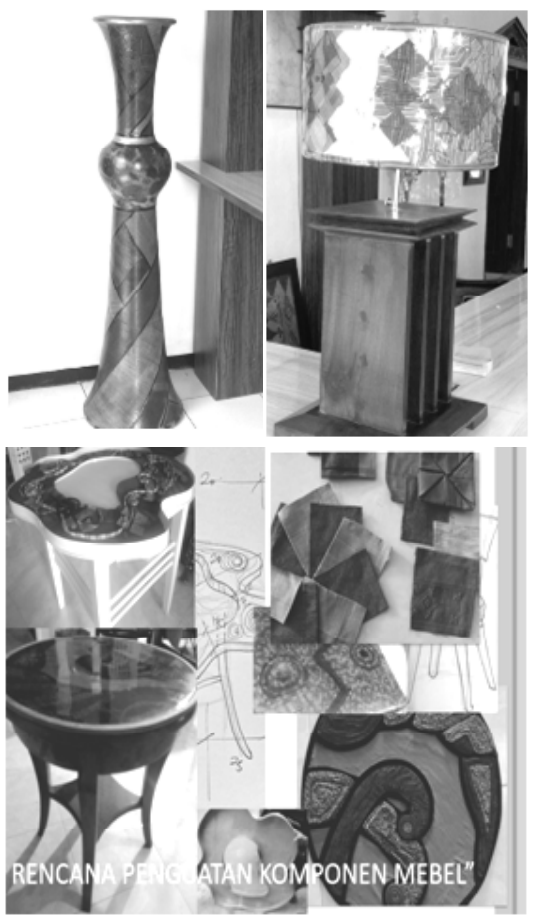

Gambar 13. Beberapa produk dengan aplikasi limbah kain lurik hasil ppm Hilink 2016 ISI Surakarta (Foto: Siti Badriyah, 2016) 
Produk berbahan corak kain tenun Lurik saat ini hanya berkutat pada barang berwujud kain, cindera mata, tas, kipas, dan dompet saja secara umum. Banyak produk yang bisa dikembangan dengan bahan dasar atau mengambil motif kain lurik seperti meja, kursi, nakas, head bed, armature lampu dan lainnya. Berikut beberapa pengembangan produk yang bisa dihasilkan dengan metode mengambil bahan dasar kain lurik atau mengambil motif kain lurik :

a. Desain Sketsel Bambu

Adapun cara membuatnya adalah sebagai berikut;

1. Siapkan rangka besi sesuai bentuk yang diinginkan sebagai rangkat utama dengan rangka pigura juga sebagai tempat kain tenun ditempatkan

2. Siapkan beberapa motif Lurik dengan ukuran sesuai pigura

3. Pasang kain Lurik tersebut ke dalam pigura

4. Setelah selesai, sketsel dapat digunakan

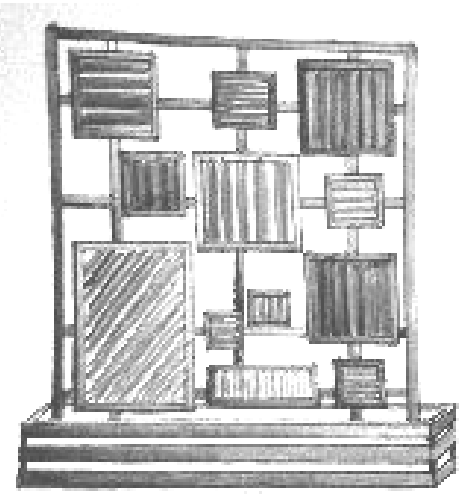

Gambar 14. Sketsa Sketsel dengan 8 Corak Lurik

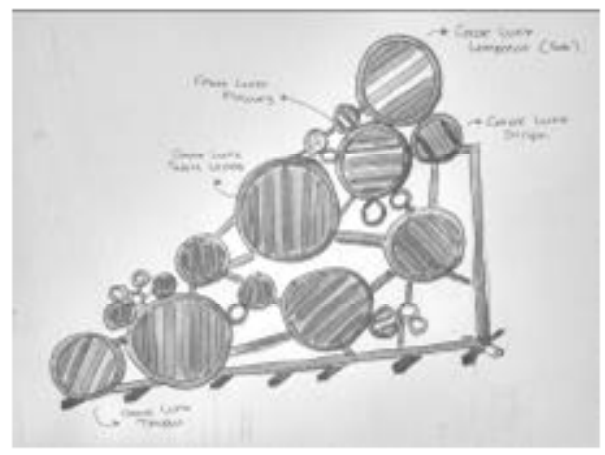

Gambar 15. Sketsa Sketsel dengan 8 Corak Lurik

\section{b. Desain Gerabah motif Lurik Kluwung}

Selain merupakan pusat kerajinan tenun lurik yang menjadi cirri khas kerajinan tenun khas Klaten, Kabupaten Klaten di Jawa Tengah merupakan salah satu kabupaten yang memiliki pusat kerajinan gerabah, diantaranya ada di Melikan, Wedi dan di daerah Bayat.
Gerabah merupakan salah satu produk unggulan diberbagai daerah di Indonesia dengan daerah penjualan dari nasional hingga internasional. Dengan inilah pengembangan / inovasi produk untuk mengangkat nilai produk lurik bisa diterapkan dengan bekerja sama dengan pengrajin gerabah di Melikan dan atau di Bayat, Klaten.

Gerabah merupakan produk local dengan memanfaatkan tanah liat sebagai bahan baku utama, dimana tanah liat memiliki tekstur yang mudah dibentuk dengan bantuan air. Tanah liat memiliki berbagai warna tergantung pada kandungan zat yang ada di dalamnya, tanah liat primer memiliki warna yang lebih pada warna putih kusam, sedangkan tanah liat sekunder dapat memiliki warna yang muda, yakni krem, coklat, abu- abu, merah jambu, kuning, kuning muda, kuning kecoklatan, kemerah-kemerah-merahan hingga kehitam-hitaman
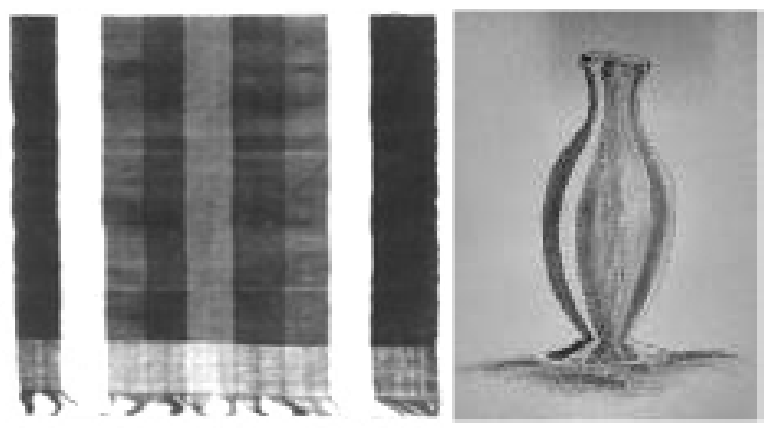

Gambar 16. Lurik Kluwung dan inovasi sketsa desain gerabah.

(Sketsa: Aquila Miko, 2016)

Salah satu motif dari Lurik adalah Lurik Kluwung. Kluwung adalah pelangi, pelangi merupakan keajaiban alam dan tanda kebesaran Tuhan Sang Pencipta. Oleh sebab itu Lurik corak kluwung dianggap sakral serta mempunyai tuah sebagai tolak bala. Secara simbolis corak kluwung dilukiskan dengan garis -garis lebar beraneka warna bagaikan warna pelangi. Corak ini dipergunakan untuk berbagai upacara sakral dalam daur kehidupan manusia antara lain: (1) Upacara Mitoni, agar anak yang dikandung lahir selamat terhindar dari bala. (2) Upacara Labuhan, biasanya dilakukan oleh kerabat keraton untuk keselamatan. (3) Upacara Mantenan, biasanya diletakkan dibawah bantal penganten dengan harapan kedua mempelai mencapai keselamatan dan kebahagiaan dalam berumah tangga seperti pesona warna pelangi.

Motif Lurik Kluwung merupakan salah satu motif lurik yang sederhana dan dapat diterapkan dalam 


\section{GE[AR Jumal seni Budyaga}

pembuatan gerabah, baik gerabah berbentuk nampan untuk wadah piring dan gelas maupun vas besar.

Cara pembuatan dari gerabah ini dengan memadukan beberapa warna tanah liat dari warna putih pucat, merah, hitam, dan orange. Adapun cara pembuatannya sebagai berikut :

1) Siapkan beberapa balok tanah liat dengan ukuran $5 \mathrm{~cm} \times 40 \mathrm{~cm}$ dengan warna putih pucat, merah, hitam, orange.

2) Susun beberapa tanah liat tadi secara vertical den berbentuk tabung serta susun warna tanah sesuai dengan motif.

3) Letakkan tabung tanah liat tadi ke alat putar untuk membentuk gerabah menjadi bentuk yang diinginkan

4) Bentuk susunan tanah liat tadi menjadi bentuk vas besar

\section{c. Desain Nampan dengan Lurik Motif Kluwung}

Sama dengan pembuatan gerabah diatas, nampan dengan corak Lurik Kluwung ini memiliki perbedaan pada bentuk dan pembuatan yang lebih sederhana. Akan tetapi, penggunaan nampan ini bisa digunakan untuk nampan wadah tempat minum / makan pada ruang makan, nampan tempat minum dan alat di meja belajar / meja baca, dan juga bisa digunakan untuk nampan tempat alat mandi di kamar mandi di sebelah washtafel.

Adapun cara pembuatannya sebagai berikut :

1) Siapkan beberapa balok tanah liat dengan ukuran $5 \mathrm{~cm} \times 40 \mathrm{~cm}$ dengan warna putih pucat, merah, hitam, orange.

2) Susun secara horizontal

3) Rekatkan balok tanah liat tersebut dengan susunan seperti pada motif, kemudian padatkan hingga tidak ada rongga udara di sela sambungan tanah liat tersebut.

4) Padatkan sekali lagi dan ratakan permukaannya dengan teknik mengerat menggunakan senar hingga permukaan susunan tanah liat tadi menjadi rata dan licin dan rapi motifnya

5) Bentuk susunan tanah liat tadi menjadi melengkung atau menjadi bentuk nampan.

6) Keringkan di bawah sinar matahari atau di panggang hingga keras.

7) Finishing dengan plitur khusus gerabah hingga mengkilat
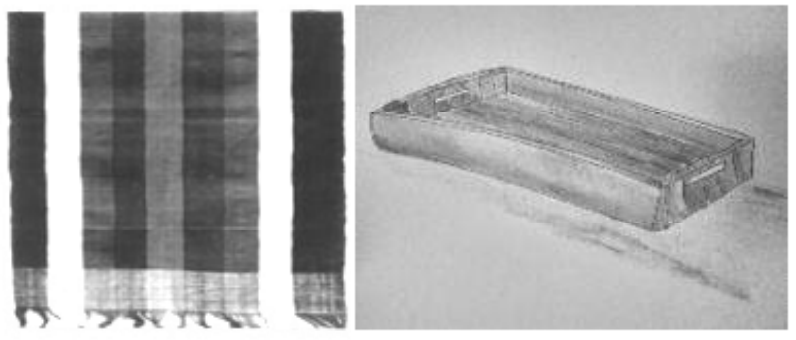

Gambar 17. Lurik Kluwung dan sketsa inovasi desain nampan

(Sketsa: Aquila Miko, 2016)

\section{d. Armature table Lamp (Wall lamp) Berbahan Bambu} dan Lurik

Corak telupat berasal dari bahasa Jawa, telu artinya tiga dan papat artinya empat adalah corak lajuran yang berjumlah $7 /$ tujuh terdiri dari satu kesatuan kelompok dengan empat lajur dan satu lagi dengan jumlah tiga lajur. Angka 7 merupakan angka keramat yang dalam kepercayaan tradisional Jawa melambangkan kehidupan dan kemakmuran yang artinya merupakan pitulungan atau pertolongan dari yang Maha Kuasa. Corak ini diciptakan oleh Sri Sul$\tan \mathrm{HB}$.

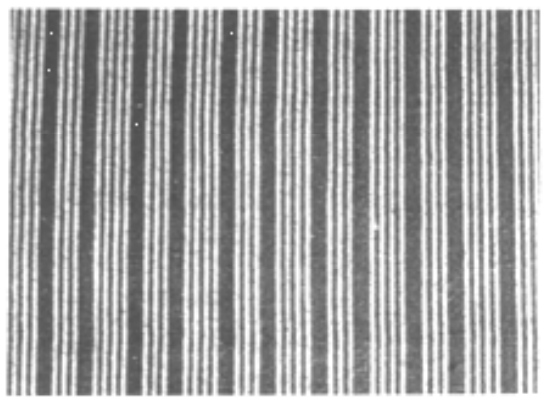

Gambar 18. Kain Lurik Telupat

Armature bambu dengan corak Lurik Telupat merupakan salah satu inovasi desain aksesoris interior yang mempunyai kesinambungan konten sumber daya local yang bisa dikembangkan di Kabupaten Klaten juga. Armature bambu ini bisa diaplikasikan sebagai wall lamp maupun table lamp di kamar tidur maupun di ruang lainnya. Warna hitam dari corak Lurik Telupat bisa berasal dari warna alami bambu petung yang mempunyai warna hitam, serta untuk warna hijau muda bisa berasal dari bambu peting.

Adapun cara pembuatan dari armature bambu dengan corak Lutik Telupat ini adalah:

1. Siapkan bambu tulung dan bambu peting berdiameter $2 \mathrm{~cm}$ dengan panjang $30 \mathrm{~cm}$.

2. Siapkan tulangan besi berbentuk kotak dengan panjang sisi $25 \mathrm{~cm}$ sebagai kerangka lampu. 
3. Susun bambu petung dan bambu peting secara vertical dan susun dengan ketinggian yang berbeda.

4. Jangan lupa susun bambu petung dan bambu peting sesuai dengan corak Lurik Telupat

5. Susun mengelilingi kerangka besi dan rekatkan dengan lem kayu atau dengan kawat.

6. Setelah selesai, finishing armature tersebut dengan plitur.

7. Keringkan dan pasang instalasi lampunya

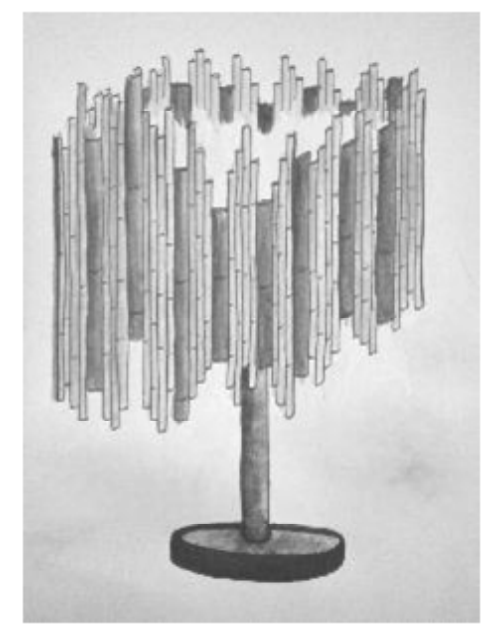

Gambar 19. Pengembangan Design Inovasi Armature Wall Lamp dengan corak Lurik Telupat

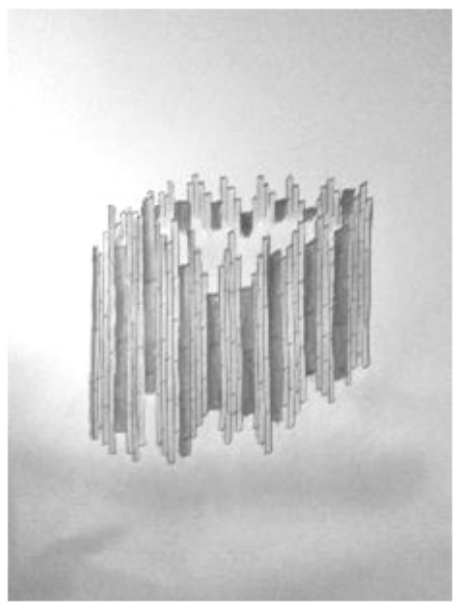

Gambar 20. Pengembangan Design Inovasi Armature Table Lamp dengan corak Lurik Telupat Keringkan dan pasang instalasi lampunya.

\section{Kesimpulan}

Bangsa Indonesia memiliki kekayaan kearifan lokal yang sangat kreatif dan memiliki citra seni yang sangat tinggi. Hal tersebut tercermin dari hasil olah karya seni. Semisal pada kain tenun Lurik tersebut, detail artistik pada kain tenun Lurik semakin membuktikan bahwa buah kreasi anak bangsa memang sangat eksklusif, patut dibanggakan dan wajib dilestarikan.

Meskipun motif dasar kain tenun Lurik hanya berupa garis-garis, namun kain tersebut memiliki banyak variasi dan ragam motik seperti corak klenting kuning, sodo sakler, lasem, tuluh watu, lompong keli, kinanti, kembang telo, kembang mindi, melati secontong, ketan ireng, ketan salak dan lain-lain. Paduannya pun tidak hanya melulu garis melainkan juga kotak-kotak, dua garis vertikal serta horizontal. Simbol yang terwujud dalam benda-benda budaya khususnya kain tenun Lurik tersebut merupakan sesuatu yang penting bagi masyarakat pendukungnya. Diharapkan, melalui kain Lurik ini terdapat pesan, nasihat dan panduan hidup yang ingin disampaikan, yang nantinya dapat terus menerus ditularkan kepada generasi berikutnya. Aplikasi pada kajian berikutnya dengan objek yang sejenis, masih sangat terbuka dan dapat dilanjutkan.

Kabupaten Klaten memiliki banyak pusat kerajinan seperti kerajinan gerabah di Melikan dan Bayat serta kerajinan bambu di daerah Delanggu merupakan asset asset yang sangat bisa diberdayakan dengan mengintegrasikan Lurik masuk dalam sertiap desain produk gerabah dan berbahan dasar tanah liat serta bambu. Harapannya adalah adanya integrasi secara menyeluruh dalam bentuk produk dalam branding dan promosi Lurik sebagai kekhasan Klaten sebagai salah satu wilayah yang memiliki pusat tenun Lurik, Gerakan diversifikasi menjadi sangat potensial dalam pelaksanaan perencanaan inovasi produk Lurik ini jika ditunjang perhatian berbagai pihak untuk mendukung bersinerginya kolaborasi antar pengrajin dalam naungan industry yang lebih kuat menaungi keberlanjutannya.

Branding sebuah wilayah sangat penting dalam pembentukan profil dan pemanfaatan sumber daya local dalam mengangkat velue sebuah wilayah. Berkesinambungannya sebuah kerajinan satu dengan yang lain menjadi salah satu cara unntuk memasarkan potensi daerah dengan skala besar, tidak dengan hanya 1 produk, tetapi dengan berbagai produk yang mempunyai ciri khas yang menonjol. Produk berbahan corak kain tenun Lurik saat ini hanya berkutat pada barang berwujud kain, cindera mata, tas, kipas, dan dompet saja secara umum. Banyak produk yang bisa dikembangan dengan bahan dasar atau mengambil motif kain lurik seperti meja, kursi, nakas, head bed, armature lampu dan lainnya. Berikut beberapa pengembangan produk yang bisa dihasilkan dengan 


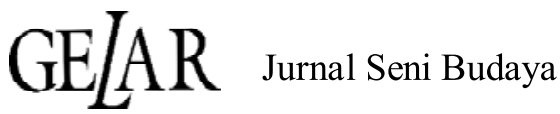

metode mengambil bahan dasar kain lurik atau mengambil motif kain lurik.

\section{Catatan Akhir:}

${ }^{1}$ Pengajar pada Prodi Desain Interior ISI Surakarta

$2 \mathrm{http}: / / \mathrm{www}$.gelorabungkarno.co.id/news/general/adiwastra-nusantara-2014-pameran-inovasi-kreatiftekstil-tradisional, diakses pada tanggal 12 November 2016, jam 12.12 WIB

${ }^{3}$ Taylor, David, Interiors an introduction, Fifth Edition, Mc Graw-Hill Companies, Inc:New York, 2011, h. 93

${ }^{4}$ Smarts, Rene, Signs, Symbols and Ornaments, Van Nostrand Reinhold Company: New york, 1975, 17

${ }^{5}$ motif udan riris ini masih sangat banyak diproduksi di Pedan meskipun tidak ada order (ready stock)

\section{KEPUSTAKAAN}

Dhorifi, Z. (2007). Tenun Tradisional Indonesia. Jakarta: Dewan Kerajinan Nasional

Djoemena, N. S. (2000). Lurik, Garis-garis Bertuah. Jakarta: Djambatan, h 5-58

Smarts, Rene, , 1975, Signs, Symbols and Ornaments, Van Nostrand Reinhold Company: New york, 17
Sugeng. (2013), Makna Simbolik motif-motif Batik Upacara Adat Mitoni di Yogyakarta. Skripsi tidak diterbitkan, Yogyakarta: Universitas Negeri Yogyakarta

Taylor, David, 2011, Interiors an introduction, Fifth Edition , Mc Graw-Hill Companies, Inc:New York, h. 93

Wahyono, M. (1981). Lurik: Suatu Pengantar. Jakarta: Wastaprema

Widodo, S. T. September - Desember (2008). Produksi Tenun ATBM dengan Aplikasi dan Variasi Pakan Non Benang. Jurnal ARS - Jurnal Seni Rupa Dan Desain, 9,24, ISBN 18297412. FSR. h. 20

\section{Narasumber:}

Bp. Rachmad, Pengusaha Lurik Pedan, CV. Sumber Sandang, Ds Jalinan, Kedungan, Pedan Klaten

Bp. Arief Purnawan ,SE .CV. Warisan Multi Tenun, Ds. Beji, Pedan, Klaten

\section{Sumber Internet:}

http://www.gelorabungkarno.co.id/news/general/ adiwastra-nusantara-2014-pameran-inovasikreatif-tekstil-tradisional, diakses pada tanggal 12 November 2016, jam 12.12 WIB 